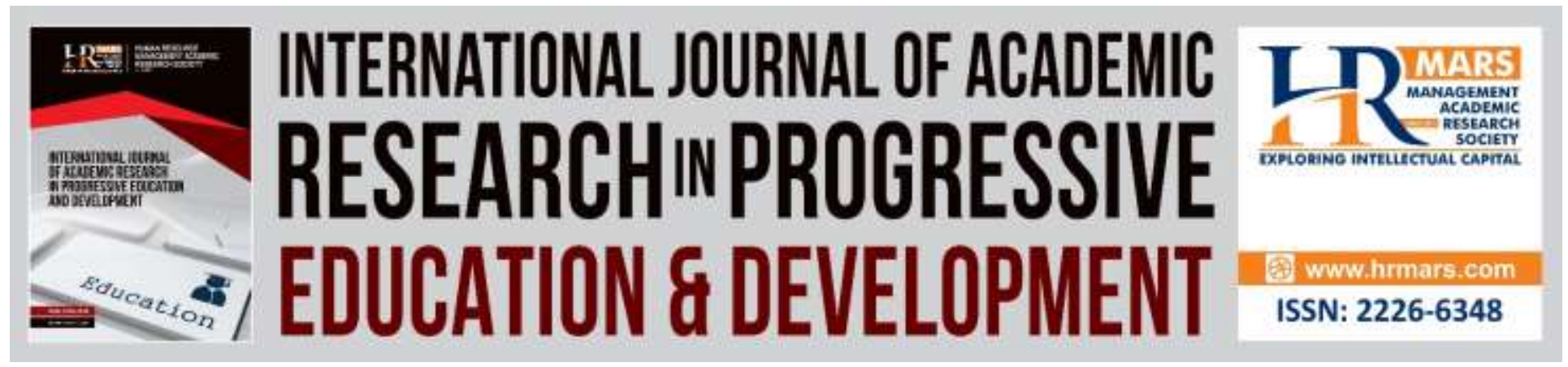

\title{
Encouraging Socioemotional Development among Preschool Children through Responsive Practices of Teacher
}

Faridah Yunus, Mohd Zafaren Zakaria

To Link this Article: http://dx.doi.org/10.6007/IJARPED/v8-i4/6777

DOI:10.6007/IJARPED/v8-i4/6777

Received: 10 November 2019, Revised: 30 November 2019, Accepted: 14 December 2019

Published Online: 31 December 2019

In-Text Citation: (Yunus \& Zakaria, 2019)

To Cite this Article: Yunus, F., \& Zakaria, Z. (2019). Encouraging Socioemotional Development among Preschool Children through Responsive Practices of Teacher. International Journal of Academic Research in Progressive Education and Development, 8(4), 864-876.

Copyright: (C) 2019 The Author(s)

Published by Human Resource Management Academic Research Society (www.hrmars.com)

This article is published under the Creative Commons Attribution (CC BY 4.0) license. Anyone may reproduce, distribute, translate and create derivative works of this article (for both commercial and non-commercial purposes), subject to full attribution to the original publication and authors. The full terms of this license may be seen at: $\underline{\text { http://creativecommons.org/licences/by/4.0/legalcode }}$

Vol. 8(4) 2019, Pg. 864 - 876

http://hrmars.com/index.php/pages/detail/IJARPED

JOURNAL HOMEPAGE

Full Terms \& Conditions of access and use can be found at http://hrmars.com/index.php/pages/detail/publication-ethics 


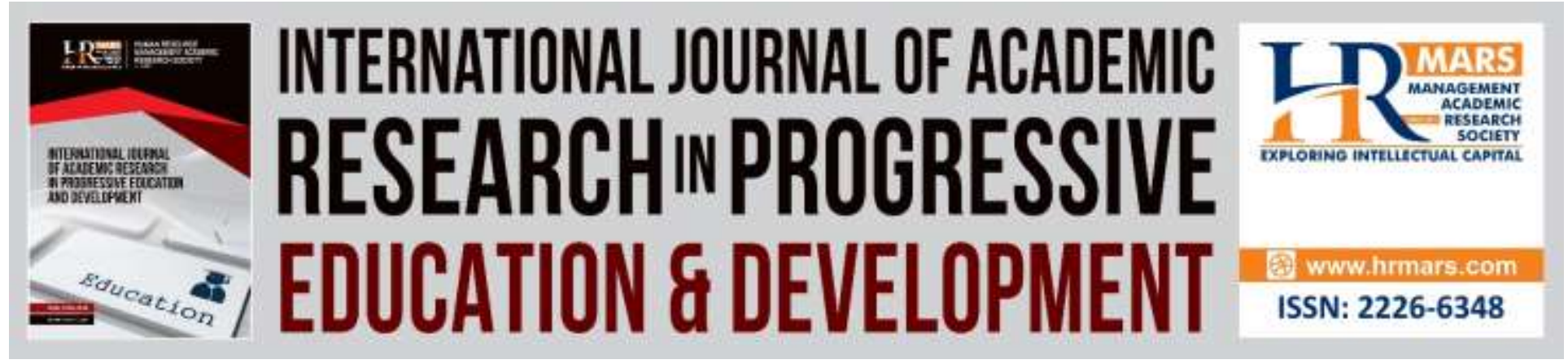

\title{
Encouraging Socioemotional Development among Preschool Children through Responsive Practices of Teacher
}

\author{
Faridah Yunus, Zafaren Zakaria \\ Centre for Education and Community Wellbeing, Faculty of Education, Universiti Kebangsaan \\ Malaysia, Malaysia \\ Email: faridahyunus@ukm.edu.my
}

\begin{abstract}
Socioemotional development of children at preschool level is crucial to ensure their healthy growth in the future. At preschool level, children receive early exposure in all aspects of development such as cognitive, physical as well as socioemotional development. Research methodology utilized in this study is the qualitative method in the form of case study. The instrument employed was face-to-face semi-structured interviews with 10 preschool teachers from the Education Ministry of Malaysia, using purposive sampling technique. Research findings clarify that there are four aspects that need to be performed by teachers to upgrade children's socioemotional development in preschool. First, teachers need to give children choice in making decisions so that they can form their own self-identity. Second, teachers praise children more frequently so that they will be motivated to behave in a better manner. Thirdly, teachers must be role models to children in order that these positive practices can become guidelines for them. Fourthly, teachers should practice positive approaches in every instance so that students feel safe when they are in preschool. In brief, teachers, as important agents in identifying socioemotional development needs of children, have great potential capacity to enhance this vital component for the children's benefit in future.

Keywords: Socioemotional Development, Preschool Children, Preschool Teachers, Teachers' Responsive Practice, Preschool

\section{Importance of Socioemotional Development to Children}

Socioemotional development of children is equally important as their cognitive and physical development (Denham et al., 2012b). It is essential to understand that children are not born with socioemotional skills (Denham, Bassett et al., 2014). This aspect is dependent on the role of parents, caregivers and teachers of the children, who are pivotal in providing guidelines and nurturing this skill.
\end{abstract}


Children's socioemotional development can give them an idea, or feeling, of who they are in this world, about how they are learning, and can also assist them to build quality relationships with others (Denham \& Bassett, 2018). It is this aspect that drives a child to communicate, connect with others, help resolve conflict, gain confidence and achieve goals (Denham, Basset, Way et al., 2014). Building a strong socioemotional foundation can aid students to develop positively and attain wellbeing in life (Denham et al., 2013a). Therefore, they would be more prepared and confident to overcome stress and be more patient when undergoing difficult moments in their adult life later.

Adults need to be fully supportive of socioemotional development within these children. This is because teachers give more priority to academic skills, regarding it as the sole means to determine the success of students in the future (Brackett et al., 2012). However, socioemotional development is also a critical element in the development of a child and needs to be accorded the appropriate attention by adults (Bierman \& Motamedi, 2015).

However, identifying socioemotional development of children is a difficult task for teachers as they lack skills in this area, compared to physical and cognitive development (Bridgeland, Bruce \& Hariharan, 2013). Hence, it is vital that teachers upgrade their skills in this aspect, so that they can help children in identifying their own socioemotional aspects.

To help children identify their socioemotional aspects, teachers must be the best role models in displaying excellent conduct so that this can be a guide for children (Denham, Bassett \& Zinsser, 2012). It is also imperative that during interaction with students, teachers instill love and kindness at all times (Kilic, 2015). Also, teachers have to give consideration for the feelings, desires, and needs of children in a particular situation (Jones, Bouffard \& Weissbourd, 2013).

Additionally, teachers have to show interest by participating in each daily activity of the child (Poulou, 2017). Teachers also must respect the children's viewpoints as they too, have the right to voice their opinions regarding a certain matter (Schonert-Reichl, 2017). Finally, teachers need to express pride towards the children for every success acheived, and to give them encouragement and support when they encounter stressful situations (Poulou, Bassett \& Denham, 2018).

\section{Socioemotional Development}

Socioemotional development is the ability of children to comprehend the feeling of others, control their own emotions and behavior, and to interact with their peers (Denham, Bassett, et al., 2014; Denham, Bassett, Way, et al., 2014). Children need socioemotional skills in order to attain the necessary basic skills in their development periods, such as cooperation, following instructions, showing self-control, and ability to focus (Blair \& Raver, 2015; CASEL, 2015b). Socioemotional development of children encompasses factors such as confidence, friendship, love, and sense of humor (Denham et al., 2015). Thus, positive relations between children and adults is the key to positive emotional and social development. 
Vol. 8, No. 4, 2019, E-ISSN: 2226-6348 @ 2019 HRMARS

Socioemotional development entails possession of a skills set within the child. This socioemotional skills set is needed to be able to identify and understand their own feelings (Denham et al., 2012c), be able to read and understand the emotional state of others accurately (John \& Bouffard, 2012), to be capable of managing emotions and have good self-expression (Humphrey, 2013), to control their own behavior (Denham et al., 2012a), have empathy for others (Denham et al., 2014) and be able to build and maintain relations with others (Jones et al., 2015).

Each of these skills are develop in tandem with the children's growth and they complement each other (Kristina et al., 2013). The foundation of socioemotional development starts from early childhood (Miller \& Goldsmith, 2017). Children would look upon the face of their loved ones, principally parents, when communication is established between them (Silkenbeumer et al., 2016). Socioemotional development among children begins when they are able to gesture to adults regarding their wants and needs (Widen et al., 2015). As such, adults must be able to establish positive relationships and give them complete love and affection so as to ensure that their socioemotional development is in accordance with their advancement in age.

\section{Responsive Practices of Teachers in Developing Socioemotional Skills among Preschool Children}

It is imperative that preschool children be given consistent attention by teachers. These children may be fearful when separated from their parents or guardians, but generally they are easily entertained, and are able to adapt themselves with new surroundings in a matter of minutes (Wanless \& Domitrovich, 2015).

Children of preshool ages are already learning of ways to interact with their peers (Yoder, 2013). These children are also capable of excelling in socoemotional skills as their mental and physical growth is happening at a phenomenal rate (Rivers et al., 2013). Thus, they are able to not only control themselves but also are able to read the emotions of others.

At this age, a child experiences a great leap into the world of socialization (Oberle \& Schonert-Reichl, 2017). When these children are exposed to social opportunities, they naturally become attracted to social involvement

(Poulou \& Basset, 2018). The role of the teacher then becomes crucial in assisting these children to handle social interaction issues when needed (Durlak, 2016). Teachers need to give words of encouragement and be able to stimulate children to solve conflicts that arise within them (Taylor et al., 2017). Therefore, teachers can help foster self-confidence among these children and create positive attitudes as they engage with their peers.

At the same time, the imagination of these children is experiencing rapid growth (Widen, 2014). Teachers play a vital role in boosting their creativity and encouraging their imagination (SchonertReichl, Kitil \& Hanson-Peterson, 2016). This opens up much more space for children in their development, in that traits of humour and ability to show empathy for others are likely to be nurtured (Shechtman \& Abu Yaman, 2012). 
The personality and emotional control of children expands at a rapid rate while they are in preschool (Amanda et al., 2013). The teacher has to teach and help students to acknowledge and understand their feelings. Subsequently, when preschool children enter primary school, they become less reliant on others (Durlak et al., 2011; Elias \& Moceri, 2012). They also become more self-confident, and free (Denham et al., 2013b). In this way, children begin to understand how to act in various social situations that involve cooperation, sharing and following instructions (Sklad et al., 2012).

Even so, it may be more challenging for a segment of children to accept their peers, compared to other children. Therefore, teachers have to assist these children by providing them with realistic aspirations so as to foster appropriate behavior (Waajid, Garner \& Owen, 2013). This can enable these children to gain greater confidence in building friendships, besides helping them to interact with their peers (Oberle et al., 2016). In this way, these socioemotional skills will continue to be with them for the rest of their lives.

\section{Research Methodology}

The qualitative method, using case study, was chosen in this research as it would provide a deeper understanding about social phenomena, in order to get a more holistic depiction (Silverman, 2016). Instruments employed for case study were semi-structured face-to-face interviews with 10 preschool teachers under the employ of the Malaysian Education Ministry. Study samples were selected based on purposive sampling technique as this enabled the researcher to choose cases based on individual traits that would then be able to provide valuable contribution towards this study (Silverman, 2016). The background and objectives of this study were explained to all participants involved in this study prior to the interviews. All transcripts were recorded digitally, and the contents were analyzed using qualitative research software Nvivi version 12. Analysis of data was done by means of thematic analysis. This process consisted of formulating codes and categories leading to the production of themes.

\section{Study Participants}

The participants involved in this study were 10 preschool teachers who had 11 to 22 years preschool teaching experience. All these selected preschool teachers had a Bachelor's degree in Early Childhood Education, with six of them also having Master's degree. All participants were female, aged between 38 and 50. Also, these preschool teachers taught students aged six, who came from family backgrounds of low and middle socioeconomic categories.

\section{Research Findings}

This section discusses results of findings obtained from the aforementioned interviews. Data was gathered through collective interviews with the 10 preschool teachers mentioned. There were four themes that were elicited through the interviews with the research participants namely: (i) allowing children to make their own choices, (ii) giving praise, (iii) being role models, and (iv) practicing positive approach. 


\section{Choices}

Teachers permit children to make decisions regarding certain matters that they like very much. Each student has his or her own preferences that differ from one another, for example in terms of game equipment, hobbies, and even favorite food.

Usually in play activities, I will allow the children to play whatever they want to ... meaning there are no restrictions. I do not say ... 'You can't play with this toy ... no'. But if it involves equipment that could be dangerous for them, I would tell them that 'This equipment is dangerous, and you cannot play with it'. The children will listen if we explain in this manner...

This helps students feel protected and makes them more obedient to rules. Additionally, students gain from making their own decisions.

I do not forbid if children come up to me and ask if they can do a certain thing, I don't wish to tell them they cannot do it because their feelings are easily hurt if we say they cannot do it. So I just let them do or play whatever they want as long as it is safe...

The decision-making process can influence the way in which children interact and behave with others, besides forging their self-identity.

We need to give choices to these kids ... if they were to just follow us, they would not be able to find out what they want to become, what they like ... if we restrict them, then it's all wasted ... the problem is if we restrict, what the student wants to do will come out later in the form of bad behavior ... if here they make noise, there will always be those who are not satisfied ... so let them do what they want, as long as we keep an eye on them ...

\section{Praise}

Teachers give encouragement orally when the children are completing a certain assignment. Praise, especially from teachers for tasks that they have performed, is deeply valued by children. I always praise these children ... for instance I may ask who had brushed their teeth. When students raise their hands, then I say 'well done' and explain a little about taking care of health ... the next day I ask the same question and there will be even more hands raised ... as for me, it is good that we always praise these children, as they will then follow what is taught ...

Therefore, praise or positive words have to be dispensed frequently and clearly to the children. The praise from the teacher must be stated very clearly about the good deed that has been performed by the children in every matter.

If the children help me to carry some things, or books ... I will praise them ... thank them ... then they will follow what we did to them, you know ... if they finish their exercises, I will say 'well done', and the child would blush ... he he

This then encourages the children to t perform a certain task in a better manner and to also help adults. Also, praise can encourage other students who listen to it.

Normally, I also look at the situation when praising the children... for instance if I see a child putting away his toys, I would say loudly, 'Very good, you are putting away your toys after playing', you know why I do this? Because I want the other students to listen to it as well. ... the next time they play with toys, they will put them away themselves and don't need to be told to do so anymore... 
DEVELOPMENT

Vol. 8, No. 4, 2019, E-ISSN: 2226-6348 @ 2019 HRMARS

\section{Role Model}

The exemplary personality of the teacher is seen as an extremely vital factor in the formation of behavior patterns among children. The countenance of the teacher deserves to be accorded much importance.

These children like to look at us ... meaning what the teacher is wearing, what color ... errr ... ask about make-up if they are girls ... he he ...I entertain them ... but at the same time I tell these children that they have to take care of their appearance, as only then others will want to be friends with us ...

The neat and clean appearance of the teacher shows that they place importance on cleanliness and comfort. This can bring to the forefront the caring attitude resident within the teachers, as they wish to present a good image to the children.

In my opinion, what teachers demonstrate to the students will become an example for them to follow because they are constantly observing what we do ... that is why teachers always need to display proper behavior in front of the children ...

As role models for children, teachers would want to make sure that they give priority on personal cleanliness and grooming. Indirectly, this attitude of caring for oneself would then be assimilated within the children.

In my class, I would watch my behavior ... because for me as a teacher, we need to show good examples to these children ... what they see, they will follow ... as for myself, I don't see anything wrong in dressing well because we want to manifest an attractive personality with these children ... then these children will also dress smartly for school and won't look shabby ...

\section{Positive Approach}

Children who come to preschool will of course feel afraid, sad and face emotional problems that can upset their peace of mind. Teachers have to adopt a positive approach such as by showing love, gentleness, being cheerful and active, having a sunny disposition, and using a gentle tone when speaking.

Every child that comes to preschool differs from the others, there are those who cry, throw tantrums ... it is the duty of the preschool teacher to make sure that the child throwing tantrums is pacified ... what I do is I will hug the child so that she feels safe ... at that time I would say, 'Look at your other friends, all of them are happy to come and learn and play together in school' ... I have never ignored children like these .. we have to care for them too.

Consequently, teachers must understand and have to create an environment that is able to fulfil the emotional and physical needs of children. At this stage, children are highly sensitive to situations around them. Emotional tranquility, trust and self-protection is extremely important to them at this stage.

Every day, when the children arrive at class, we are already waiting at the door, give them smiles, ask how they are ... all sorts of things ... it's nothing other than the campaign of the caring teacher, this process makes the children feel appreciated, they will feel happy at school, we can see children becoming more confident when in class ... 
Besides being fair, firm and tolerant, a teacher also needs to be considerate when dealing with children.

Have to show positive traits to these children ... I speak in a proper, gentle manner, if I see any who are careless with their shoes or books ... usually l'd call the name and tell them what their mistake was ... for example, 'Aina, I see that your shoes are not arranged properly, please arrange properly', in a gentle way so that the child can learn something from this ... I want them to feel, 'Oh, doing this way is wrong ... I have to do it this way, only then is it right'.

The way of educating a child needs to be understood in a wholesome manner by preschool teachers. This can ensure that the child develops in a healthy way intellectually, spiritually and emotionally. Thus, teaching of children should be able to appeal to them and motivate them in a positive direction so that they are courageous enough to face new situations using their intellect, spirituality and emotions. Teachers are agents who play critical roles in identifying socioemotional development at preschool level.

\section{Discussion}

Early educators of children, in nurturing their socioemotional aspect and aiding them to attain success and wellbeing in life, need to be aware of the children's emotional development first (CASEL, 2015a). The reason for this is because in developing the socioemotional aspect of children and assisting them to attain success and wellbeing, teachers need to have knowledge of the way in which children's emotions develop (Durlak et al., 2015). Thereafter, teachers can know the suitable methods and techniques for developing the socioemotional aspects of children and help them achieve success and wellbeing. (Meyers et al., 2015).

Socioemotional growth plays an important role in the life of a child (CASEL, 2013) as it adds joy in daily experiences of children, besides being a motive force for their actions, and shaping patterns of the form of actions that will be undertaken by them (Calvano, 2017). Also, emotions also play a role in the perception of an individual towards the environment and determining the form of modification that he performs (Bassett et al., 2012).

Socioemotional development is the outcome of maturity and also learning ( $O^{\prime}$ Conner et al., 2017). Moreover, maturity in physical and mental development of children influences their emotions (Lintunen \& Gould, 2015). Therefore, socioemotional development takes on its own specific pattern when the child matures. As the development of an individual increases, the socioemotional aspect also is altered due to his overall growth (Von Suchodoletz et al., 2014). Briefly stated, the emotional development of the child can be observed right from birth as he develops in tandem with the increase in age.

The relationship between the child at this stage and his family strongly influences the ability of the child to communicate with other people (John Greenberg \& Crowley, 2015). This is because children who feel that they are constantly loved will find it easier and faster to communicate and interact with their peers and also adults (Amanda et al.,2013). On the other hand, if the child is too dependent on other people, or feels that he is not safe and at peace, then usually he will find it difficult to accept the presence of other people (Denham \& Bassett, 2018). 
At this stage, the emotions of children change quickly (Durlak et al., 2015). This happens because children normally express their emotions in an open way (Denham et al., 2015). Furthermore, children at preschool level have less understanding of a particular situation due to their thinking and experiences which are still limited (Denham et al., 2012b). Besides that, the attention span of children is limited, so their attention shifts to other topics very easily (Denham, Bassett, Way et al., 2014).

Teachers have to understand children's socioemotional aspects so that they can identify abilities of children upon knowing their level of development (Kilic, 2015). Teachers also can get to know each child and prepare appropriate stimuli for children (Von Suchodoletz et al., 2014). Hence, teachers' knowledge towards the development level of children can help in expanding their socioemotional aspect in heading towards success and wellbeing in future.

\section{Conclusion}

When educating children, there are many aspects that need to be considered by preschool teachers to make sure that their socioemotional development is in concord with their growth development. Teachers have to think about cognitive, physical and socioemotional development in their teaching in preschool (CASEL, 2013; John, Bouffard \& Weissbourd, 2013; Schonert-Reichl, 2016). This is because the socioemotional aspect is of equal importance as cognitive and physical development. Just like these two skills, socioemotional skills depend on the guidance and teaching of teachers in preschool (Yoder, 2013). Therefore, it is important to ensure that teachers consistently give emphasis in all aspects of development and not focus solely on cognitive aspects.

Teachers should give specific positive praise for things children have performed or said. The time spent in preschool is the time that is of very high quality for children in expanding all aspects of themselves (Rivers, 2013; Wanless \& Domitrovich, 2015). Teachers need to understand that children develop at different rates and have unique personalities (Waajid, Garner \& Owen, 2013). Teachers need to set realistic standards for children and present better opportunities for them to succeed and gain self-confidence. Thus, with the assistance of teachers, children are able to increase socioemotional skills and thereafter develop meaningful relationships throughout their lives.

\section{Acknowledgement}

The study was supported by the grant from the Faculty of Education, Universiti Kebangsaan Malaysia, GG-2019-003.

\section{References}

Amanda, P. W., Jessica, E. V. W., Virginia, E. V. \& Jason, T. D. (2013). Children's engagement within the preschool classroom and their development of self-regulation. Early Education and Development, 24:2, 162-187. doi: 10.1080/10409289.2011.628270. 
Bassett, H. H., Denham, S., Mincic, M., \& Graling, K. (2012). The structure of preschoolers' emotion knowledge: Model equivalence and validity using a structural equation modelling approach. Early Education and Development, 23, 259-279.

Bierman, K. L., \& Motamedi, M. (2015). Social-emotional learning programs for preschool children. In J. Durlak, C. Domitrovich, R. P. Weissberg, \& T. Gullotta (Eds.), The handbook of social-emotional learning: Research and practice (pp. 1-36). New York, NY: Guilford Press.

Blair, C., \& Raver, C. C. (2015). School readiness and self-regulation: A developmental psychobiological approach. Annual Review of Psychology, 66, 711. doi.org/10.1146/annurev-psych-010814-015221.

Brackett, M. A., Reyes, M. R., Rivers, S. E., Elbertson, N. A., \& Salovey, P. (2012). Assessing teachers' beliefs about social and emotional learning. Journal of Psychoeducational Assessment, 30, 219-236.

Bridgeland, J., Bruce, M., \& Hariharan, M. (2013). The Missing Piece: A National Survey on How Social and Emotional Learning Can Empower Children And Transform Schools. Washington, DC: Civic Enterprises.

Calvano, N. (2017). Body psychotherapy and social and emotional learning: an integrative model. International Body Psychotherapy Journal, 16, 73-87.

CASEL. (2013). Effective Social and Emotional Learning Programs: Preschool and Elementary School Edition. Chicago, IL: Author.

CASEL. (2015a). District Guide for Social and Emotional Learning. Chicago, IL: Author.

CASEL. (2015b). Effective Social and Emotional Learning Programs: Middle and High School Edition. Chicago, IL: Author.

Denham, S. A., \& Bassett, H. H. (2018). "You hit me! That"s not nice and it makes me sad!!": Relations of young children's social information processing and early school success. Early Child Development and Care, 1-15. doi:10.1080/03004430.2018.1491562.

Denham, S. A., Bassett, H. H., Brown, C., Way, E., \& Steed, J. (2015). "I know how you feel": Preschoolers' emotion knowledge contributes to early school success. Journal of Early Childhood Research, 13(3), 252-262.

Denham, S. A., Bassett, H. H., Mincic, M., Mincic,Kalb, S., Way, E., Wyatt, T., \& Segal, Y. (2012b). Social-emotional learning profiles of preschoolers' early school success: A personcentered approach. Learning and Individual Differences, 22, 178-189.

Denham, S. A., Bassett, H. H., Thayer, S. K., Mincic, M. S., Sirotkin, Y. S., \& Zinsser, K. (2012a). Observing preschoolers' social-emotional behavior: Structure, foundations, and prediction of early school success. The Journal of Genetic Psychology, 173(3), 246-278.

Denham, S. A., Bassett, H. H., Way, E., Kalb, S., Warren-Khot, H., \& Zinsser, K. (2014). "How would you feel? What would you do?" Development and underpinnings of preschoolers' social information processing. Journal of Research in Childhood Education, 28, 182-202.

Denham, S. A., Bassett, H. H., Way, E., Mincic, M., Zinsser, K., \& Graling, K. (2012c). Preschoolers' emotion knowledge: Self-regulatory foundations, and predictions of early school success. Cognition and Emotion, 26(4), 667-679. 
Denham, S. A., Bassett, H. H., Way, E., Zinsser, K., \& Wyatt, T. M. (2014). How preschoolers' socialemotional learning predicts their early school success: Developing theory-promoting, competency-based assessments. Infant and Child Development, 23(4), 426-454.

Denham, S. A., Bassett, H. H., \& Zinsser, K. (2012). Early childhood teachers assocializers of young children's emotional competence. Early Childhood Education Journal, 40(3), 137-143. http://dx.doi.org/10.1007/s10643-012-0504-2.

Denham, S. A., Kalb, S., Way, E., Warren-Khot, H., Rhoades, B. L., \& Bassett, H. H. (2013a). Social and emotional information processing in preschoolers: Indicator of early school success? Early Child Development and Care, 183(5), 667-688.

Denham, S. A., Way, E., Kalb, S., Warren-Khot, H., \& Bassett, H. (2013b). Preschoolers' social information processing and early school success: The challenging situations task. British Journal of Developmental Psychology, 31(2), 180-197.

Durlak, J. A. (2016). Programme implementation in social and emotional learning: Basic issues and research findings. Cambridge Journal of Education, 46, 333-345. doi:10.1080/0305764X.2016.1142504.

Durlak, J. A., Domitrovich, C. E., Weissberg, R. P., \& Gullotta, T. P. (2015). Handbook of Social and Emotional Learning: Research and Practice. New York, NY: The Guilford Press.

Durlak, J. A., Weissberg, R. P., Dymnicki, A. B., Taylor, R. D., \& Schellinger, K. B. (2011). The impact of enhancing students' social and emotional learning: A meta-analysis of school based universal interventions. Child Development, 82, 405-432.

Elias, M. J., \& Moceri, D. C. (2012). Developing social and emotional aspects of learning: the American experience. Research Papers in Education, 27(4), 423-434. doi:10.1080/02671522.2012.690243.

Humphrey, N. (2013). Social and Emotional Learning: A Critical Appraisal. London, UK: Sage.

Jones, D. E., Greenberg, M., \& Crowley, M. (2015). Early social-emotional functioning and public health: The relationship between kindergarten social competence and future wellness. American Journal of Public Health, 105, 2283-2290. doi:10.2105/AJPH.2015.302630.

Jones, S. M., \& Bouffard, S. M. (2012). Social and emotional learning in schools: From programs to strategies. Social Policy Report, 26(4), 1-33.

Jones, S. M., Bouffard, S. M., \& Weissbourd, R. (2013). Educators' social and emotional skills vital to learning. Phi Delta Kappan, 94, 62-65.

Kilic, S. (2015). Preschool teachers' emotional socialization responses to 4-6year-old Turkish preschoolers' emotional expressions. European Journal of Research on Education, 3(1), 53-63. doi.org/10.1016/S0885-2006(99)00007-.

Kristina J. H., Craig S. B., Elizabeth A. S., Denham, S. A. \& Bassett, H. H. (2013). Preschoolers' emotion expression and regulation: Relations with school adjustment. The Journal of Genetic Psychology: Research and Theory on Human Development, 174:6, 642-663, doi:10.1080/00221325.2012.759525.

Lintunen, T., \& Gould, D. (2015). Developing social and emotional skills. In Routledge Companion to Sport and Exercise Psychology. Routledge. doi.org/10.4324/9781315880198.ch40.

Meyers, D. C., Gil, L., Cross, R., Keister, S., Domitrovich, C. E., \& Weissberg, R. P. (2015). CASEL Guide for Schoolwide Social And Emotional Learning. Chicago, IL: CASEL. 
Miller, M. M. and Goldsmith, H. H. (2017) Profiles of Social-Emotional Readiness for 4-Year-Old Kindergarten. Front. Psychol. 8:132. doi: 10.3389/fpsyg.2017.00132.

O’Conner, R., De Feyter, J., Carr, A., Luo, J. L., Romm, H., (ED), R. E. L. M.-A., \& International, I. C. F. (2017). A review of the literature on social and emotional learning for students ages 38: characteristics of effective social and emotional learning programs (Part 1 of 4). REL 2017-245. Regional Educational Laboratory Mid-Atlantic. Regional Educational Laboratory Mid-Atlantic.

Oberle, E., \& Schonert-Reichl, K. A. (2017). Social and Emotional Learning: Recent Research and Practical Strategies for Promoting Children's Social and Emotional Competence in Schools. Handbook of Social Behavior and Skills in Children, 175-197.doi:10.1007/978-3-31964592-6_11.

Oberle, E., Domitrovich, C. E., Meyers, D., \& Weissberg, R. P. (2016). Establishing systemic social and emotional learning approaches in schools: The need for school-wide implementation. Cambridge Journal of Education, 46, 277-297.

Poulou, M. S. (2017). Social and Emotional learning and teacher-student relationships: Preschool teachers and students' perceptions. Early Childhood Education Journal, 45(3), 427-435.

Poulou, M. S. \& Bassett, H. H. (2018) Children's emotional and behavioral responses to peer provocation and early school adjustment. Pastoral Care in Education, 36:3, 205-222. doi: 10.1080/02643944.2018.1479351

Poulou, M. S., Bassett, H. H., \& Denham, S. A. (2018). Teachers' perceptions of emotional intelligence and social-emotional learning: students' emotional and behavioral difficulties in u.s. and greek preschool classrooms. Journal of Research in Childhood Education, 32(3), 363-377. doi:10.1080/02568543.2018.1464980.

Rivers, S. E., Brackett, M. A., Reyes, M. R., Elbertson, N. A., \& Salovey, P. (2013). Improving the social and emotional climate of classrooms: A clustered randomized controlled trial testing the RULER approach. Prevention Science, 14, 77-87.

Schonert-Reichl, K. A. (2017). Social and emotional learning and teachers. Future of Children, 27(1), 137-155.

Schonert-Reichl, K. A., Kitil, M. J., \& Hanson-Peterson, J. (2016). Teachers first: A national scan of teacher preparation programs and social and emotional learning. A report prepared for the Collaborative for Academic, Social, and Emotional Learning (CASEL). Vancouver, BC: University of British Columbia.

Shechtman, Z., \& Abu Yaman, M. (2012). SEL as a component of a literature class to improve relationships, behavior, motivation, and content knowledge. American Educational Research Journal, 49(3), 546-567. doi:10.3102/0002831212441359.

Silkenbeumer, J., Schiller, E. M., Holodynski, M., \& Kärtner, J. (2016). The role of co-regulation for the development of social-emotional competence. Journal of Self-Regulation and Regulation, 2, 11-26.

Silverman, D. (2017). Doing Qualitative Research. A Practical Handbook. 5th Edition. Sage. ISBN 978-1446260159.

Sklad, M., Diekstra, R., Ritter, M. D., Ben, J., \& Gravesteijn, C. (2012). Effectiveness of schoolbased universal social, emotional, and behavioral programs: Do they enhance students' 
development in the area of skill, behavior, and adjustment? Psychology in the Schools, 49(9), 892-909. doi:10.1002/pits.21641.

Taylor, R., Oberle, E., Durlak, J. A., \& Weissberg, R. P. (2017). Promoting positive youth development through school-based social and emotional learning interventions: A metaanalysis of follow-up effects. Child Development, 88(4), 1156-1171.

Suchodoletz, V. A., Fäsche, A., Gunzenhauser, C., \& Hamre, B. K. (2014). A typical morning in preschool: Observations of teacher-child interactions in German preschools. Early Childhood Research Quarterly, 29(4), 509-519. doi.org/10.1016/j.ecresq.2014.05.010.

Waajid, B., Garner, P. W., \& Owen, J. E. (2013). Infusing social emotional learning into the teacher education curriculum. The International Journal of Emotional Education, 5(2), 31-48.

Wanless, S. B., \& Domitrovich, C. E. (2015). Readiness to implement school-based socialemotional learning interventions: Using research on factors related to implementation to maximize quality. Prevention Science, 16, 1037-1043.

Widen, S. C. (2014). The development of children's concepts of emotion. DIm. L. F. Barrett, M. Lewis, \& J. M. Haviland-Jones (Eds.), Handbook of emotions (4th ed. New York: Guilford. in press.

Widen, S. C., Pochedly, J. T., \& Russell, J. A. (2015). The development of emotion concepts: A story superiority effect in older children and adolescents. Journal of Experimental Child Psychology, 131, 186-192.doi:10.1016/j.jecp.2014.10.009.

Yoder, N. (2013). Teaching the Whole Child: Instructional Practices That Support Social And Emotional Learning In Three Teacher Evaluation Frameworks. Washington, DC: American Institutes for Research Center on Great Teachers and Leaders. Please follow APA Referencing style. Authors are recommended to use Endnote or Mendeley for referencing purpose. 